\title{
HOMENAJE A LA DRA. Ma EUGENIA GÁLVEZ EN SU JUBILACIÓN ACADÉMICA
}

\section{Emilio de Santiago Simón}

Pecaría de ingenuo redomado si pretendiese, como quien desvela un arcano insondable, explicar a nuestra amiga homenajeada el nexo etimológico que vincula la voz castellana "jubilación" con su matriz latina correspondiente, cuyo bagaje semántico tan impregnado está de las ideas de alegría, de regocijo, de júbilo en suma. Digo que pecaría de ingenuo, no porque de todos sea conocida sobradamente la acepción del término aludido y su preclara estirpe léxica, sino porque, como acontece con cualquier otra realidad articulada mediante la palabra, acaso no en su aparente fisonomía, pero sí en algún recóndito transfondo encierre algo que no nos suene a un primer golpe de oído con nitidez meridiana. Las palabras -estoy plenamente convencido en mi fuero interno- tienen sus arcanos, sus extrañas conexiones, su magia indefinible e interior, de idéntica manera a como, imaginariamente, parece que también ocurriese en el opaco e impenetrable ámbito que riela frío tras el azogue de los espejos. Al mirarlos, casi siempre, me asalta la duda, de si no más reflejarán la simple y desnuda verdad que a ellos se asoma o, por el contrario, nos devolverán sólo parte de ésta, en tanto que, con inexplicable cautela, celan a nuestra mirada otra dimensión, otra cara de las cosas menos evidente, pero qúe, sin duda, también le es propia.

Con estos quizás pretenciosos recursos metafóricos empleados o bien sin género de valimiento literario alguno, querida Eugenia, quiero decirte, aquí y ahora, que ambos sospechamos con perspicacia beduina lo que, bajo la idea de júbilo o de alegría del étimo latino de "jubilación", pueda ocultarse; tú sobre todo que hoy comienzas, como quien dice, a vivir ese estado, puedes comprobar la verdad del aserto con mayor propiedad que yo, aunque, bien es cierto, con una acaso menguada experiencia aún.

Alegría, gozo, satisfacción, pues claro que sí. Cómo si no podría entenderse la cosa. Mas esos legítimos sentimientos de regocijo que hoy te embargan, aunque los callases, se sabría que no te los provoca únicamente el hecho envidiable de haber llegado a una meta administrativa convencional en óptimas condiciones y rodeada de afecto, reconocimiento, simpatía. Hay en tu corazón algo más: lo que la médula soterraña de la palabra a que antes aludíamos esconde, lo que los espejos no reflejan. Hay, como sobreañadida a los acontecimientos presentes, una sensación intrasferible de plenitud que sabe a deber cumplido, que habla de vivencias lejanas en el tiempo, que exhala el perfume pretérito y suave de los recuerdos que siempre habrán de acompañarte. 
Como soy por naturaleza atrevido e imprudente, voy a intentar un juego apetecible. Por un momento voy a entrar, virtualmente por supuesto, en tu memoria sin otras artes malabares que las que los muchos años de amistad me permiten. De inmediato y como en un caleidoscopio, imágenes diversas comienzan a revolotear en torno a mí iluminadas por un haz de luz difusa, quizá desprendida de algún olvidado foco que alguien no se atrevió a apagar para no dejar la escena enteramente a oscuras. Comienzo a ver, en medio del laberinto de fotogramas, a la joven estudiante universitaria que duda en su elección y, al fin, entra a cursar estudios en la Facultad de Filosofía y Letras de la Complutense; luego encamina sus pasos hacia esa extraña opción de Filología Semítica que a todos sorprende y desorienta; los primeros contactos con sinuosos y en apariencia herméticos grafismos; las primeras amistades de esas que o se marchitan con el correr del tiempo definitivamente o se hacen eternas; los cursos superiores y las incipientes orientaciones hacia el futuro; los primeros y titubeantes cometidos de trabajo; el Instituto Hispano-Árabe...y, como al final de un largo pasillo, la tarea universitaria.

Llegados a este punto, todo parece adquirir un sentido nuevo y una apariencia diferente. Aquella despierta e inquieta estudiante de un antaño próximo ha encontrado ya su camino, su definitivo y verdadero camino.

Cual si todo lo viese a través de la lechosa opalina de los celuloides rancios, percibo las primeras clases, los inicios de una singladura docente esforzada y laboriosa, mas también, en ocasiones, gratificante y gozosa. El cotidiano quehacer de las lecciones en el aula, con su forzosamente ralentizado ritmo; "estos de la parte izquierda del encerado son los paradigmas de los nombres de acción de la forma primera; aquéllos los plurales sanos y los fractos..." (¡Dios, qué inolvidable pedagogía la de Asín Palacios!) ¿Los ves, Eugenia, están sentados y expectantes? ¿Los puedes imaginar intentando pergeñar la traducción de un difícil texto del Libro de los avaros de al-Y̧ăhiz? ¿Los recuerdas?: Son tu prolongación, son tus alumnos. De la mayor parte, puede que hayas perdido el rastro; de otros no. Algunos están hoy aquí entre nosotros. Han venido a acompañarte en el día que "oficialmente" simulas tu adiós a la Universidad. A posta, he entrecomillado oficialmente y he utilizado el verbo simular. Lo sabemos los dos: tú no te vas de verdad, tú no te puedes ir (A mi cabeza acuden unos versos de P. Salinas, docente también como tú en este Alma Mater Hispalense, que explican el intríngulis :"Porque el no tiene un revés, / -quien lo dice no lo sabe -, ..."). Como es obvio, el revés de ese no a que alude el poeta es un sí. Y es que hoy sólo festejamos una apariencia. Un acto transeúnte. Podríamos llamarlo, con su tantico de sorna, "una despedida, pero menos"; que bien hubiese valido como título para una comedia de Mihura.

Si te fueses de verdad, si te jubilases realmente como se jubilan los trastos administrativos que ingresaron soñando con esa efeméride, sería terrible, amiga mía, porque parecería que nunca ocurrió nada, que no fueron vívidas y reales tus lecciones, tu dedicación, tu afectuoso magisterio. Serían un fraude o una ilusión optica las horas transcurridas de estudio y de preparación, los momentos gratos de charla entre colegas, los sinsabores taimados. Tus manos ágiles nunca hubieran tocado, entonces, tanto folio por corregir; nunca las hubieras empolvado con el blanco untuoso de las tizas. Tendrías que renunciar, sin más, a la parte alícuota que posees en la formación de muchos, a tu "maternidad" en orden a ese ser sustancial y profundo 
que dan los saberes que prodigaste. Decía R. Pérez de Ayala que "La función educativa no es tanto de enseñanza (proveer un cúmulo inorgánico de datos, noticias o conocimientos) cuanto la formación y desarrollo del espíritu; y esto ya desde Sócrates que por eso mismo se definió como comadrón de almas".

Por tal motivo, vuelvo a repetirte que tu ida de la Universidad no es definitiva, más aún, que tu ida no es; vamos, que ni siquiera es factible. Que tú te quedas aquí de alguna forma para la que no encuentro definición ni nombre. Que tú, con el ala mojada de tantos rocíos sevillanos, como en la bella cita de Ibn Labbāna que abre un libro de nuestro llorado Don Emilio, no puedes volar ya de esta tribu a la que te unen indisolubles lazos de briosa sangre académica.

Luego de lo dicho, creo que he agotado mi gavilla de argumentos puestos en acción, fundamentalmente, para disuadirte de cualquier idea de nostalgia o de tristeza que, llegado el caso, te parara en mientes al iniciar esta nueva etapa de tu vida. Personalmente, yo soy de la opinión de que, muy al contrario de dejarte imbuir por no importa qué sensación dolorosa que pueda asaltarte, más bien debes acogerte a la objetiva realidad que vives, la que estás experimentando ahora en toda su magnitud e intensidad. Debes saber leer entre sus líneas, desentrañar todo lo que parece querer mostrarte que nuestras vidas, la tuya, la mía, la de aquel anónimo ciudadano que pensativo descansa en un banco del parque, son un complejo entramado de sueños y de avatares, cuya dimensión lógica difícilmente llegaremos algun día a comprender. El esfuerzo de existir tiene, demasiado a menudo por cierto, un abierto divorcio con la razón e inclusive se sitúa en sus antípodas tranquilamente. La cosa, para qué engañarnos, es así de inexorable y no admite mejoras, qué le vamos a hacer. Pero, no obstante, observa, Eugenia, que aunque mucho sea lo andado, mucho lo gozado o lo sufrido, nunca falta a este totum revolutum que nos envuelve en su vorágine cotidiana un determinado y constante sentido en el cual nos reconocemos. Y esa identidad, desdibujada tal vez o precaria y tenue si quieres, es lo que en verdad somos. Lo que, a trancas y barrancas, permanece y nos queda, como si fuese el jugo íntimo de un fruto que un dios irónico nos entregara al nacer. Muchos han dado en llamarlo destino, otros vocación, puede también nombrarse con otros nombres. No importa ni hace al casp en este momento concreto entrar en distingos. Pero sí me interesa de modo particular señalarte su importancia y lo poderoso de su terrible y adhesiva fuerza centrípeta. Tal es ésta, que no podemos escapar a su órbita de influencia ni sustraernos a sus exigencias, aunque desesperadamente lo buscásemos. En el fondo, parece que se tratara de un cierto determinismo fatalista que a los estudiosos de nuestras materias resulta acaso familiar.

Pues bien, si me has seguido, fijate qué pequeña reflexión he urdido a propósito de una palabra y del amplio espectro de su significado. Con mi mendicante filosofía tan improvisada, he ido pulsando algunos registros de distinta índole y he perseguido la idea de situar los acontecimientos en su lugar debido. Me queda la duda de haber conseguido siquiera una infinitesimal materia de mi propósito. De todos modos, cualquiera que sea la circunstancia final y aunque reconozca, de todas todas, la parvedad de mi aportación al acto, no quiero terminar mi turno de palabra sin insistir en que, como te es fácil advertir, existen razones de peso para invitarte a que consideres lo que de certero tienen las ideas mal pergeñadas que he 
venido a ofrecerte. Me dolería que se confundiesen con eufemismos o con una vacua y amable quincallería de argumentos. Espero que no habrán sido tampoco -de eso estoy seguro- la consabida retahila de laudes hueca u obligada que parecen exigir los eventos como este que nos ocupa. Sabe el Cielo que sólo me ha movido a hablarte, lo que mueve a quienes aprendimos por experiencia y trabajos a distinguir las voces de los ecos. He venido como leal amigo, y de esta guisa tornaré a mi voluntario exilio alhambreño. Pero antes de que el momento llegue, quiero dejarte con mis palabras el polen de unas hipotéticas flores de tributo. Y, como acontece a las célebres "dos gardenias" del viejo Machín, con mis flores quiero decirte que no te vayas para siempre, que sigas en el tajo de alguna manera que, para el caso, inventes; que nunca renuncies a ser lo que el sevillano A. Machado decía en el elogio a su maestro Giner de los Ríos y que yo, con retoques adecuados, gloso: nunca, nunca dejes de ser entre los tuyos lo que has sido, alma. 